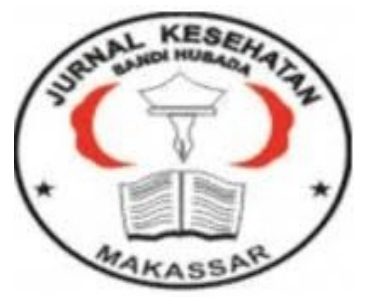

\author{
Jurnal Ilmiah Kesehatan Sandi Husada
}

hhttps://akper-sandikarsa.e-journal.id/JIKSH

Vol 9, No, 1, Juni 2020, pp; 95-102

p-ISSN: 2354-6093 dan e-ISSN: 2654-4563

DOI: $10.35816 /$ jiskh.v10i2.222

\title{
Intensitas Bermain Game Online dan Motivasi Belajar dengan Prestasi Belajar Mahasiswa Fakultas Kedokteran
}

The Intensity to Play Online Games and Learning Motivation with Student Achievement in Medical Faculty Students

\section{Bio Lerianza 1, Deviani Utami ${ }^{2}$, Supriyati ${ }^{3}$, Achmad Farich ${ }^{4}$ \\ ${ }^{1}$ Program Studi Kedokteran Fakultas Kedokteran Universitas Malahayati \\ 2Departemen IKAKOM, Fakultas Kedokteran Universitas Malahayati \\ ${ }^{3}$ Departemen Psikologi, Fakultas Kedokteran Universitas Malahayati \\ ${ }^{4}$ Departemen IKAKOM, Fakultas Kedokteran Universitas Malahayati}

Artikel history:

Received; 15 Maret 2020

Revised; 18 Maret 2020

Accepted; 19 Maret 2020

\begin{abstract}
Abstrak
Latar Belakang: Perkembangan teknologi internet termasuk di Indonesia sangat pesat. Salah satu dari teknologi internet yang berkembang sangat pesat adalah game online. Pada dasarnya, mahasiswa bermain game online hanya sebatas hiburan untuk penghilang penat setelah aktivitas belajar sehari-hari.Bermain game online dengan intensitas yang tinggi dapat menimbulkan kecanduan atau ketergantungan secara terus menerus yang nantinya akan mempengaruhi tingkat konsentrasi belajar mahasiswa tersebut. Tujuan: Mengetahui hubungan antara intensitas bermain game online dan motivasi belajar dengan prestasi belajar pada Mahasiswa Fakultas Kedokteran Umum Universitas Malahayati Angakatan 2018. Metode: Desain penelitian ini menggunakan pendekatan analatik observasional dengan desain cross sectional. Teknik pengambilan sampel pada penelitian ini menggunakan metode purposive sampling dan didapatkan jumlah sampel sebanyak 118 orang. Analisis data menggunakan uji korelasi Spearman's. Hasil: Hasil uji statistik bivariat korelasi Spearman's didapatkan masing-masing nilai $p$ - value = 0,000 dengan nilai korelasi data yaitu -0,353 pada intensitas bermain game online dan $p$-value $=0,000$ dengan nilai korelasi data yaitu 0,515 pada motivasi belajar. Kesimpulan: Terdapat hubungan yang bermakna antara intensitas bermain game online dan motivasi belajar dengan prestasi belajar pada Mahasiswa Fakultas Kedokteran Umum Universitas Malahayati Angakatan 2018.
\end{abstract}

Abstract

Background: The development of internet technology, 
including in Indonesia, is very rapid. One of the fastest growing internet technologies is online gaming. Basically, students playing online games are only limited to entertainment for relieving tired after daily learning activities. Playing online games with high intensity can cause addiction or dependency continuously which will later influence the level of student concentration of learning. Purposes Knowing the relationship between the intensity of playing online games and learning motivation with learning achievement in the Students of the Faculty of General Medicine, University of Malahayati Force 2018. Methodology: The design of this study used an observational analytic approach with cross sectional design. The sampling technique in this study used a purposive sampling method and obtained a total sample of 118 people. Data analysis uses Spearman's correlation test. Result Spearman correlation bivariate statistical test results obtained each value of $p$-value $=0,000$ in the intensity of playing online games and $p$-value $=0,000$ in learning motivation. Conclusion: There is a significant relationship between the intensity of playing online games and learning motivation with learning achievement in the Students of the Faculty of General Medicine, University of Malahayati Force 2018.

Keywords:

Intensitas Bermain;

Game Online;

Motivasi Belajar;

Prestasi Belajar;
Coresponden author:

Email: lerianzabio@gmail.com

artikel dengan akses terbuka dibawah lisensi CC BY-4.0

\section{PENDAHULUAN}

Prestasi belajar merupakan hasil kemampuan yang telah di peroleh peserta didik setelah mengikuti program kegiatan belajar pada waktu tertentu bisa seperti perubahan keterampilan, tingkah laku, serta pengetahuan dan akan di nilai dan di ukur yang selanjutnya di wujudkan berupa angka dan pernyataan (Astuti, 2015).

Prestasi Belajar di Universitas Malahayati di kutip berdasarkan IPK dari hasil presurvei data dari Medical Education Unit (MEU), di dapatkan data pada Mahasiswa Fakultas Kedokteran Umum Universitas Malahayati angkatan 2016, 2017, dan 2018 tercatat sebanyak 41\%, 28\% dan 35\% secara berturut yang masih memiliki IPK dibawah 2,76. Dari data tersebut dapat ditarik kesimpulan bahwa terdapat data yang fluktuatif, dimana persentase dan angka krieteria memuaskan terdapat penurunan dan peningkatan dalam tiga tahun terakhir ini, yang nantinya dapat berpengaruh pada tingkat angka keberhasilan dalam kegiatan pembelajaran di Universitas Malahayati. Faktor dari dalam dan faktor dari luar merupakan faktor yang dapat mempengaruhi prestasi belajar. Hasil belajar adalah suatu keberhasilan yang di dapat oleh para siswa, yakni prestasi belajar siswa di sekolah yang mewujudkan dalam bentuk angka. (Lahir, 2017),

Dari hasil ini bisa di jelaskan bahwa pengertian faktor luar adalah faktor yang ada dari luar pelajar yang meliputi lingkungan sosial dan lingkungan alam instrumentasi yang 
merupakan kurikulum, pengajar atau guru, fasilitas dan sarana dan juga administrasi. Sedangkan faktor dalam adalah yang terdapat dari dalam individu tersebut yang melibatkan pancaindra dan kondisi fisik. Game online merupakan faktor luar yang berhubungan dengan prestasi belajar (Pande \& Marheni, 2015).

Prestasi belajar di pengaruhi oleh banyak faktor, Salah satunya faktor yang memengaruhi prestasi belajar ialah intesitas bermain Game online dan motivasi belajar. Intensitas merupakan suatu kekuatan sikap dan identitas setiap orang yang merupakan keinginan untuk melakukan sesuatu secara sungguh-sungguh yang diukur dari waktu yang dipergunakan pada suatu aktivitas yang telah dipilih. (Pande \& Marheni, 2015).(Radinal mukhtar, 2015) mengatakan bahwa prestasi belajar juga pada umumnya meningkat jika motivasi untuk belajar bertambah. Motivasi dibagi menjadi dua yaitu instrinsik dan ekstrinsik. Sesuai dengan pendapat Mukhtar yang mengatakan bahwa motivasi belajar siswa merupakan daya penggerak bagi siswa untuk melakukan sesuatu. Peran motivasi adalah menumbuhkan gairah dan semangat untuk belajar sehingga dapat di katakan motivasilah yang mendorong siswa untuk melakukan kegiatan belajar.

Menurut (Cheng et al., 2018) berpendapat jika pada intensitas penggunaan gadget seseorang, memiliki dua pernyataan yang harus di perhatikan, yaitu frekuensi gadget yang di gunakan serta intensitas menggunakan gadget. Game online merupakan permainan yang dapat dimainkan oleh satu atau beberapa pemain, dan jaringan internet menghubungkan gadget dari pengguna satu ke pengguna yang lain. Perkembangan game online menjadikan individu atau seseorang yang bermain game menjadi kecanduan. Selain itu, dalam game juga terkandung alur cerita yang panjang berkesinambungan, terusmenerus sehingga terjalin dari berbagai masalah yang harus di selesaikan oleh pemain , faktor-faktor yang mempengaruhi remaja dalam bermain game online adalah Faktor budaya, Faktor sosia ldan Faktor Pribadi.

(Psa, 2017), komponen kecanduan game online yang sekaligus menjadi patokan membuat sebuah pengukuran dengan enam kriteria untuk mengetahui adiksi (kecanduan) atau tidaknya seseorang. enam kriteria tersebut adalah salience, tolerance, euphoria, relapse and reinstatement, withdrawal, conflict. Game online paling banyak digunakan oleh siswa, game online memiliki sifat candu sehingga waktu siswa banyak dihabiskan untuk bermain game online. Intensitas bermain Game online yang terjadi di sekolah didapat dari hasil penelitian tentang hubungan intensitas bermain game online pada salah satu sekolah di yogyakarta terdapat hubungan yang signifkan antara intensitas bermain game online dengan prestasi belajar (Nuhan, 2016).

\section{Metode}

Desain dari Penelitian ini adalah survei observational Cross Sectional, penelitian ini dilakukan pada bulan Februari 2020 di Universitas Malahayati Bandar Lampung, sasarannya kepada mahasiswa universias malahayati, subjek penelitian ini adalah mahasiswa fakultas kedokteran Universitas Malahayati angkatan 2018 yang berjumlah 118 orang, prosedur penelitian dengan memberikan kuisioner dan melihat IPK semester dua responden, kuisioner yang digunakan ada dua yaitu kuisioner intensitas bermain game online dan motivasi belajar, Analisis dilakukan terhadap dua variabel yang di teliti yaitu hubungan intensitas bermain game online dan motivasi belajar dengan Prestasi belajar. Untuk menguji hipotesis antara variabel bebas (intensitas bermain game online dan motivasi belajar) dengan variabel terikat (prestasi belajar) menggunakan teknik analisis regresi berganda dikarenakan pada penelitian ini terdapat dua variabel bebas, untuk mengetahui masing-masing hubungan variabel bebas dengan variabel terkait 
digunakan uji alternatif yaitu uji korelasi spearman karena hasi uji normalitas menghasilkan data tidak terdistribusi normal (Saputra \& Semuel, 2013).

\section{Hasil Dan Pembahasan}

Tabel 1. Analisis intensitas bermain Game Online dengan Prestasi Belajar Pada Mahasiswa Fakultas Kedokteran Universitas Malahayati Angkatan 2018 Correlations

\begin{tabular}{|c|c|c|c|c|}
\hline & & & $\begin{array}{c}\text { intensitas } \\
\text { bermain Game } \\
\text { Online }\end{array}$ & $\begin{array}{l}\text { Prestasi } \\
\text { Belajar }\end{array}$ \\
\hline \multirow[t]{6}{*}{$\begin{array}{l}\text { Spearman' } \\
S\end{array}$} & \multirow{3}{*}{$\begin{array}{c}\text { intensitas } \\
\text { bermain Game } \\
\text { Online }\end{array}$} & $\begin{array}{c}\text { Correlation } \\
\text { Coefficient }\end{array}$ & 1.000 & -.353 \\
\hline & & Sig. (2-tailed) & . & .000 \\
\hline & & $\mathrm{N}$ & 118 & 118 \\
\hline & \multirow[t]{3}{*}{ Prestasi Belajar } & $\begin{array}{l}\text { Correlation } \\
\text { Coefficient }\end{array}$ & -.353 & 1.000 \\
\hline & & Sig. (2-tailed) & .000 & $\cdot$ \\
\hline & & $\mathrm{N}$ & 118 & 118 \\
\hline
\end{tabular}

Berdasarkan tabel diperoleh hasil analisis antara intensitas bermain Game Online dengan prestasi belajar dengan nilai $p$-value $=0.000$. Hal ini menunjukkan bahwa ada korelasi yang baik antara intensitas bermain Game Online dengan prestasi belajar dan juga menampilkan nilai korelasi data yaitu -0.353. Nilai ini menunjukkan korelasi antara intensitas bermain Game Online dengan prestasi belajar pada penelitian ini adalah sedang dan bernilai negatif, yang artinya semakin tinggi tingkat intensitas bermain Game Online semakin menurunkan prestasi belajar mahasiswa.

Tabel 2. Hubungan Motivasi Belajar dengan Prestasi Belajar Pada Mahasiswa Fakultas Kedokteran Universitas Malahayati Angkatan 2018

\begin{tabular}{llrr}
\hline & Correlations & & \\
\hline & & $\begin{array}{c}\text { Motivasi } \\
\text { belajar }\end{array}$ & $\begin{array}{c}\text { Prestasi } \\
\text { Belajar }\end{array}$ \\
\hline $\begin{array}{l}\text { Spearman' Motivasi Belajar } \\
\boldsymbol{s}\end{array}$ & $\begin{array}{l}\text { Correlation } \\
\text { Coefficient }\end{array}$ & 1.000 & .515 \\
& Sig. (2-tailed) &. & .0 .000 \\
& $\mathrm{~N}$ & 118 & 118 \\
\cline { 2 - 4 } & Correlation & .515 & 1.000 \\
& Coefficient & .000 & \\
& Sig. (2-tailed) & 118 & 118
\end{tabular}

Berdasarkan tabel diperoleh hasil analisis antara motivasi belajar dengan prestasi belajar dengan nilai $p$-value $=0.000$. Hal ini menunjukkan bahwa ada korelasi yang baik antara motivasi belajar dengan prestasi belajar dan juga menampilkan nilai korelasi data yaitu 0.515. Nilai ini menunjukkan korelasi antara motivasi belajar dengan prestasi belajar pada penelitian ini adalah kuat dan bernilai positif, yang artinya semakin tinggi motivasi belajar semakin baik prestasi belajar mahasiswa. 


\section{Pembahasan}

\section{Hubungan Intensitas Bermain Game Online dengan Prestasi Belajar}

Hasil analisis antara intensitas bermain Game Online dengan Prestasi belajar diperoleh nilai $p$-value $=0.000$. Hal ini menunjukkan bahwa ada korelasi yang baik antara intensitas bermain Game Online dengan Prestasi belajar dan juga menampilkan nilai korelasi data yaitu. -0.353. Nilai ini menunjukkan korelasi antara intensitas bermain Game Online dengan prestasi belajar pada penelitian ini adalah sedang dan bernilai negatif, yang artinya semakin tinggi tingkat intensitas bermain Game Online semakin menurunkan prestasi belajar mahasiswa. Hasil penelitian ini sejalan dengan penelitian Ni Putu pada siswa SMP Negeri 1 Kuta di mana diperoleh hasil p-value $=0.001$ yang berarti ada hubungan yang signifikan antara kecanduan game Online dengan prestasi belajar.

Penelitian dari (Granic et al., 2014).menemukan bahwa terdapat beberapa manfaat positif dari bermain game. Salah satunya adalah meningkatnya kemampuan spasial yang berperan penting dalam prestasi di bidang teknologi, permesinan, dan matematika. Selain itu, dinyatakan pula bahwa siswa yang rutin bermain game akan memiliki pemusatan perhatian yang lebih baik yang juga berlaku di bidang akademik.

Dampak positif lainnya adalah pemain game strategi dapat meningkatkan kemampuan berpikir dan menganalisa suatu kasus tertentu. Para pemain game juga memiliki fokus yang lebih dibandingkan dengan orang lain. Permainan game juga mampu membuat anak atau remaja menghilangkan stres dan kepenatan dari aktivitas sekolah. Manfaat lainnya yaitu secara tidak langsung pemain game akan menguasai beberapa bahasa asing yang biasanya ada pada dialog game dan prolog game. Dalam beberapa tipe game seperti game action strategi juga bermanfaat untuk meningkatkan kemampuan dalam bernegosiasi, mengambil keputusan, ataupun melakukan perencanaan, dan berpikir strategis dalam situasi tertentu (Fauziah, 2013).

Maka dari penelitian di atas, peneliti berpendapat bahwa yang dapat ditarik adalah terdapat hubungan signifikan intensitas bermain game online dengan prestasi belajar. Apabila skor variable intensitas bermain game online meningkat, maka skor variabel prestasi belajar akan mengalami penurunan. Sebaliknya, apabila skor variabel intensitas bermain game online menurun, maka skor variabel prestasi belajar akan mengalami peningkatan. intensitas bermain game online berhubungan dengan prestasi belajar karena game online membuat siswa terbiasa dengan stimulus dinamis yang kaya warna seperti yang ditemukannya dalam game online, sehingga menganggap stimulus tak bergerak dengan warna yang monoton seperti buku dan tulisan di papan tulis membosankan. Selain itu, game online berperan sebagai distraktor yang membuat motivasi belajar siswa berkurang.

\section{Hubungan Motivasi dengan Prestasi Belajar}

Hasil analisis antara motivasi belajar dengan prestasi belajar dengan nilai $p$-value $=0.000$. Hal ini menunjukkan bahwa ada korelasi yang baik antara motivasi belajar dengan prestasi belajar dan juga menampilkan nilai korelasi data yaitu 0.515. Nilai ini menunjukkan korelasi antara motivasi belajar dengan prestasi belajar pada penelitian ini adalah kuat dan bernilai positif, yang artinya semakin tinggi ,motivasi belajar semakin baik prestasi belajar mahasiswa.

Selain itu ada juga fungsi lain yaitu, motivasi dapat berfungsi sebagai pendorong usaha dan pencapaian prestasi, karena secara konseptual motivasi berkaitan dengan prestasi dan hasil belajar. Adanya motivasi yang baik dalam belajar akan menunjukkan hasil yang 
baik. Dengan kata lain, adanya usaha yang tekun dan terutama didasari adanya motivasi, maka seseorang yang belajar itu akan dapat melahirkan prestasi yang baik. Intensitas motivasi seorang mahasiswa akan sangat menentukan tingkat pencapaian prestasi belajarnya (Husna et al., 2017)

Motivasi sangat terkait dalam belajar, dengan motivasi inilah mahasiswa akan meningkatkan minat, kemauan dan semangat yang tinggi dalam belajar serta tekun dalam proses belajar, dengan motivasi juga kualitas prestasi belajar mahasiswa dapat diwujudkan. Motivasi belajar sangat diperlukan dalam kegiatan belajar sebab tidak semua materi belajar menarik minat mahasiswa atau sesuai dengan kebutuhannya. Motivasi ini dapat berasal dari dosen, teman, keluarga maupun lingkungan yang akan memicu keinginan mahasiswa untuk terus belajar. Dengan adanya motivasi tersebut dalam diri mahasiswa dapat memberikan suatu semangat dalam menjalankan proses belajar sehingga apa yang diharapkan mahasiswa dapat tercapai.

\section{Simpulan Dan Saran}

Berdasarkan hasil analisis dan pembahasan penelitian, maka dapat diambil kesimpulan mengenai hubungan antara intensitas bermain game online dan motivasi belajar dengan prestasi belajar pada Mahasiswa Fakultas Kedokteran Umum Universitas Malahayati Angakatan 2018 sebagai berikut :

1. Dari hasil penelitian menunjukkan sebagian besar prestasi belajar pada mahasiswa Fakultas Kedokteran Universitas Malahayati angkatan 2018 adalah kategori Baik sebanyak 69 orang (58.5\%).

2. Dari hasil penelitian menunjukkan sebagian besar intensitas bermain Game Online pada mahasiswa Fakultas Kedokteran Universitas Malahayati angkatan 2018 adalah kategori sedang sebanyak 66 orang (55.9\%).

3. Dari hasil penelitian menunjukkan sebagian besar motivasi belajar pada mahasiswa Fakultas Kedokteran Universitas Malahayati angkatan 2018 adalah kategori cukup sebanyak 37 orang (31.4\%).

4. Hasil analisis antara intensitas bermain Game Online dengan Prestasi belajar diperoleh nilai $p$-value $=0,000$. Hal ini menunjukkan bahwa ada korelasi negatif antara intensitas bermain Game Online dengan Prestasi belajar dan juga menampilkan nilai korelasi data yaitu $-0,353$. Nilai ini menunjukkan korelasi antara intensitas bermain Game Online dengan hasil prestasi belajar pada penelitian ini adalah sedang dan bernilai negatif, yang artinya semakin tinggi tingkat intensitas bermain Game Online semakin menurunkan hasil prestasi belajar mahasiswa.

5. Hasil analisis antara motivasi belajar dengan hasil prestasi belajar dengan nilai $p$-value $=0,000$. Hal ini menunjukkan bahwa ada korelasi positif antara motivasi belajar dengan hasil prestasi belajar dan juga menampilkan nilai korelasi data yaitu 0,515. Nilai ini menunjukkan korelasi antara motivasi belajar dengan hasil prestasi belajar pada penelitian ini adalah kuat dan bernilai positif, yang artinya semakin tinggi ,motivasi belajar semakin baik hasil prestasi belajar mahasiswa.

Peneliti menyarankan kepada pengajar untuk dapat menarik minat pada saat menjelaskan materi ajar dikarenakan ada keterkaitan yang erat antara minat dan motivasi dimana jika motivasi belajar seseorang tinggi maka akan meningkatkan prestasi belajar. Peneliti menyarankan kepada mahasiswa untuk dapat meningkatkan motivasi belajar dari dalam diri selain itu motivasi juga bisa di dapatkan dari lingkungan sekitar contohnya seperti keluarga,teman dan pengajar dimana nanti akan timbul suatu timbal balik yang baik untuk meningkatkan motivasi belajar. Peneliti menyarankan kepada peneliti 
selanjutnya untuk dapat lebih memperhatikan faktor-faktor lain yang mungkin dapat meningkatkan hubungan yang mempengaruhi prestasi belajar.

\section{Daftar Rujukan}

Astuti, S. P. (2015). Pengaruh Kemampuan Awal dan Minat Belajar terhadap Prestasi Belajar Fisika. Formatif: Jurnal Ilmiah Pendidikan MIPA, 5(1), 68-75. https://doi.org/10.30998/formatif.v5i1.167

Cheng, C. P., Wu, K. L., Mai, C. C., Yang, C. T. C. K. C. T., Hsu, Y. S., Yan, B. H. B. H., Wüthrich, R., Abou Ziki, J. D., Paul, L., Korah, L. V., Sarkar, B. R., Doloi, B. N., Bhattacharyya, B., Zhang, Z., Huang, L., Jiang, Y. Y., Liu, G., Nie, X., Lu, H., ... Little, A. D. (2018). No 主観的健康感を中心とした在宅高齢者における

健康関連指標に関する共分散構造分析Title. International Journal of Machine Tools and Manufacture, 5(1), 86-96. https://doi.org/10.1016/j.ijmachtools.2009.09.004

Fauziah, E. R. (2013). Pengaruh Game Online Terhadap Perubahan Perilaku Anak Smp Negeri 1 Samboja. Lmu Komunikasi, 1(3), 1-16. ejournal.ilkom.fisip-unmul.ac.id

Granic, I., Lobel, A., \& Engels, R. C. M. E. (2014). The benefits of playing video games. American Psychologist, 69(1), 66-78. https://doi.org/10.1037/a0034857

Husna, N., Normelani, E., \& Adyatma, S. (2017). Hubungan Bermain Games dengan Motivasi Belajar Siswa Sekolah Menengah Pertama (SMP) di Kecamatan Banjarmasin Barat. JPG (Jurnal Pendidikan Geografi), 4(3), 1-14.

Lahir, S. dkk. (2017). Peningkatan Prestasi Belajar Melalui Model Pembelajaran yang Tepat pada Sekolah Dasar Sampai Perguruan Tinggi. Edunomika, 01(01), 1-5.

Nuhan, M. Y. G. (2016). Hubungan Intensitas Bermain Game Online Dengan Prestasi Belajar Siswa Kelas Iv Sekolah Dasar Negeri Jarakan Kabupaten Bantul Yogyakarta. Basic Education, 5(6), 494-501. http://journal.student.uny.ac.id/ojs/ojs/index.php/pgsd/article/view/1236/111 2

Pande, N. P. A. M., \& Marheni, A. (2015). Hubungan Kecanduan Gameonlinedengan Prestasi Belajar Siswa Smp Negeri 1 Kuta. Jurnal Psikologi Udayana, 2(2), 163-171. https://doi.org/10.24843/jpu.2015.v02.i02.p05

Psa, M. (2017). No Title ㅃ․ April, 15-16.

Radinal mukhtar. (2015).

Saputra, R., \& Semuel, H. (2013). Analisa Pengaruh Motivasi, Persepsi, Sikap Konsumen Terhadap Keputusan Pembelian Mobil Daihatsu Xenia di Sidoarjo. Jurnal Manajemen Pemasaran, 1(1), 1-12. 